\title{
Sequence Stratigraphic Interpretation of FX-1 and FX-2 wells, Onshore Western Niger Delta, Nigeria
}

\author{
${ }^{1}$ AMIEWALAN, FO; ${ }^{2}$ LUCAS, FA
}

\author{
Department of Geology, University of Benin, Benin City, Nigeria. \\ *Corresponding AuthorEmail: amiewalanflorence@gmail.com; drfalucas@gmail.com
}

\begin{abstract}
The area of study is a portion of the Greater Ughelli Depobelt in Niger Delta Basin. The main aim of the paper is to interpret the sequence stratigraphy of FX-1 and FX-2 wells by employing data sets from biostratigraphic data and well logs. Standard laboratory techniques were used for data treatment while computer software such as Petrel and StrataBugs were used for data simulation, processing, integration and interpretation. Sedimentology, interpreted gamma ray and resistivity well logs integrated with biostratigraphic data were utilized to define the candidate maximum flooding surfaces and sequence boundaries. The wells have the following distributions of sequences: FX-1 well have five depositional sequences with eight candidate maximum flooding surfaces at depths $10011 \mathrm{ft}$., $9509 \mathrm{ft}$., $9437 \mathrm{ft}$., $6362 \mathrm{ft}$., $5752 \mathrm{ft}$., $5507 \mathrm{ft}$., $5161 \mathrm{ft}$. and $4816 \mathrm{ft}$. dated $34.0 \mathrm{Ma}, 33.0$ Ma, 31.3 Ma, 28.1 Ma, 26.2 Ma, 24.3 Ma, 23.2 Ma and 22.0 Ma and seven candidate sequence boundaries at 9616 ft., $6656 \mathrm{ft} ., 6116 \mathrm{ft}$., $5639 \mathrm{ft} ., 5424 \mathrm{ft} ., 4859 \mathrm{ft}$. and $4581 \mathrm{ft}$. dated $33.3 \mathrm{Ma}, 29.3 \mathrm{Ma}, 27.3 \mathrm{Ma}, 24.9 \mathrm{Ma}, 23.7 \mathrm{Ma}$, 22.2 Ma and 21.8 Ma, respectively. FX-2 well have four depositional sequences, five candidate MFSs were identified at $7764 \mathrm{ft}$., $7196 \mathrm{ft}$., $6721 \mathrm{ft}$., $5862 \mathrm{ft}$. and $5571 \mathrm{ft}$. dated 34.0 Ma, 33.0 Ma, 31.3 Ma, 28.1 Ma and 24.3 Ma and five candidate SBs at $6941 \mathrm{ft} ., 6029 \mathrm{ft}$., $5688 \mathrm{ft}$., $5653 \mathrm{ft}$. and $5542 \mathrm{ft}$. dated $32.4 \mathrm{Ma}, 29.3 \mathrm{Ma}, 27.3 \mathrm{Ma}, 24.9 \mathrm{Ma}$ and 23.7 Ma respectively. The correlation of the two wells and sequence stratigraphic interpretation is a supplementary understanding of the subsurface geology of the Onshore, western Niger Delta area of Nigeria.
\end{abstract}

\section{DOI: https://dx.doi.org/10.4314/jasem.v24i2.17}

Copyright: Copyright (C) 2020 Amiewalan and Lucas. This is an open access article distributed under the Creative Commons Attribution License (CCL), which permits unrestricted use, distribution, and reproduction in any medium, provided the original work is properly cited.

Dates: Received: 16 November 2019; Revised: 11 January 2020; Accepted: 22 February 2020

Keywords: Bio-stratigraphic data, Well logs, Sequence stratigraphy, Well correlation.

The area of study is a portion of the Greater Ughelli Depobelt in Niger Delta Basin. Two wells (FX-1 and FX-2) used for this research are one of the several developmental boreholes penetrated in the oil-rich Niger Delta, situated Onshore, Niger Delta Basin, Nigeria. FX-1 well is located at geographic coordinates of Longitude E5 ${ }^{0} 33^{\prime} 55^{\prime \prime} .58$ and Latitude $\mathrm{N}^{0}{ }^{1} 1^{\prime} 32^{\prime \prime} .64$ while FX-2 well is located at geographic coordinates of Longitude E5 $5^{0} 33^{\prime} 36^{\prime \prime} .86$ and Latitude $\mathrm{N}^{0}{ }^{1} 8^{\prime} 25^{\prime \prime} .43$. Fig. 1a. Distance between the two wells is $2,022.30 \mathrm{ft}$. / $617 \mathrm{~m}$ and the direction for FX-1 well is NE while the direction for FX-2 well is $\mathrm{SW}$ as shown in figure $1 \mathrm{~b}$. The two wells are fairly deep and they penetrated both the Benin and Agbada Formations of the Niger Delta. Sequence stratigraphy is the investigation of rocks that are hereditarily correlated in the framework of chronostratigraphically confined surface. Van Wagoner et al., (1990). The three principal schools of thought on sequences are: The Exxon (1977-1988) school is centered on unconformity. The depositional sequence is based on highstand and lowstand systems tracts, confined by subaerial unconformity, followed by a regressive surface of marine erosion, and then a correlative conformity (regularly hard to identify). According to Hart, (2005), the model is widely accepted and applied in the hydrocarbon industry. The Galloway, (1989) school is established on maximum flooding surfaces. The depositional sequences is constrained by maximum flooding surfaces regularly referred to as regressive-transgressive sequences (R-T). The benefit of this genetic stratigraphic model is that only one type of surface (maximum flooding surface) is defined and is easy to identify. Conversely, an interpreter should take caution since there is the likelihood of unconformities lying inside the sequences. Hart, (2005). The Emery, (1993) school is known as the Emery and Johannessen model of transgressiveregressive (T-R) sequences is founded on subaerial unconformity and transgression surfaces. The depositional sequences are bounded by subaerial unconformities and maximum regressive surfaces with two systems tracts. The transgressive systems tract lies between the sequence boundary at the base and the maximum flooding surface at the top. The regressive systems tract lies between the maximum flooding surface at the base and the sequence boundary at the top. It is the newest model, simple to apply, but not 
widely used. Hart, (2005). The fundamental unit of sequence stratigraphy is the depositional sequence. A sequence is defined as a relatively conformable succession of genetically related strata bounded by unconformities or their correlative conformities. van Wagoner et al., (1990). It emphasizes phases of deposition and non-deposition (associated with periods of rising and falling of sea level). Several workers such as Evamy et al., (1978); Tuttle, et al., (1999); Weber and Daukoru, (1975); Obaje, (2013); Ojo and Gbadamosi, (2013); Okengwu and Amajor, (2015); Alege, (2017); Ozumba and Amojor (1999); Ajayi and Okosun (2014); Ifeoluwadun and Saka (2018) have worked on the biostratigraphy, sequence stratigraphy, structural geology, sedimentology and petroleum geochemistry of the Niger Delta. Nonetheless, in most of the published and unpublished works, incorporated method in sequence stratigraphic interpretation is absent. The use of sequence stratigraphy methods to sedimentary basin investigation has brought about a new technique of dividing, analyzing and mapping sedimentary rock. Kelly et al., (2000). Unrecognized stratigraphic traps can be revealed and identified which could significantly intensify the finding of hydrocarbon potential in the study area. Furthermore, an improved understanding of the depositional environment, lithological facies and numerous depositional sequences of the area of study which could be extended laterally to a regional extent in the Niger Delta. The aim of this study is to demarcate the major stratigraphic units and systems tracts in the study area of the Niger Delta, by integrating stacking pattern, sedimentologic and biostratigraphic data to delineate candidate chronostratigraphic surfaces.

Geological Setting: The Niger Delta is situated at the apex of the Gulf of Guinea on the west coast of Central Africa. As posited by Whiteman (1982), the Niger Delta clastic section was formed along the aulacogen

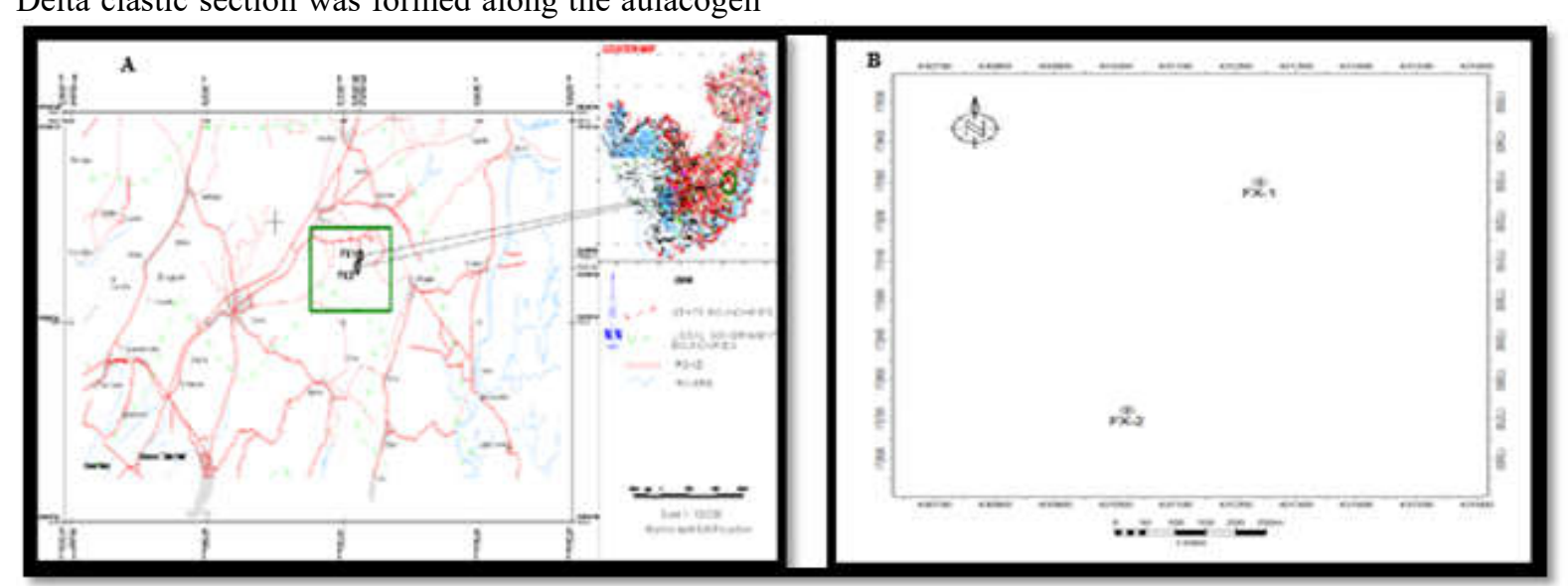

Fig 1a: Map Displaying Location of FX-1 and FX-2 Wells. (Wells Renamed for proprietary reasons). Fig 1b: NE-SW line section of both

Wells. that was initially established in the course of the disintegration of the South American and African plates in the Late Jurassic. According to Evamy et al., (1978); Doust and Omatsola, (1990), the regressive Niger Delta consist of a wedge of clastic sediments of up to $12 \mathrm{~km}$ thick formed by a succession of offlap cycles. Short and Stauble, (1967); Knox and Omatsola, (1989); Tuttle et al., (1999, etc.) recognized three main Formations in the Niger Delta sedimentary basin, namely: the Akata Formation, Agbada Formation and Benin Formation. The Akata Formation is composed of marine prodelta shales and turbidite sands that have been deposited since the Paleocene and is believed to be the main source rock within the basin. The Agbada Formation is made up of paralic siliciclastics and are considered to be the main deltaic sequence that establish the petroleum reservoirs of the basin capped by sandy fluvial Benin Formation which consists largely of non-marine sands with a few shaly intercalations. Esan, (2002). Deposited since the Oligocene. Fig 2.

\section{MATERIALS AND METHODS}

Three hundred and eighty two (382) ditch cutting samples from interval $2900 \mathrm{ft}$. - $9650 \mathrm{ft}$. of a total depth of $6750 \mathrm{ft}$. from FX-2 well, six hundred and seventy eight (678) ditch cutting samples from interval $15 \mathrm{ft}$. - $10,185 \mathrm{ft}$. of a total depth of $10,170 \mathrm{ft}$. from FX-1 well and ASCII data were provided by Nigerian Petroleum Development Company (NPDC) of Nigeria. Additional materials includes sample scale (Mettler PC 440 digital balance), Reflected and Transmitted light Microscopes (Zeiss binocular 475022 model, wild Heerbrugg M5 - 81796 model and B-Bran Binocular), sony digital camera (14.1Mega Pixels), computer soft wares (petrel 2011 model, Stratabug 2.0 software). 


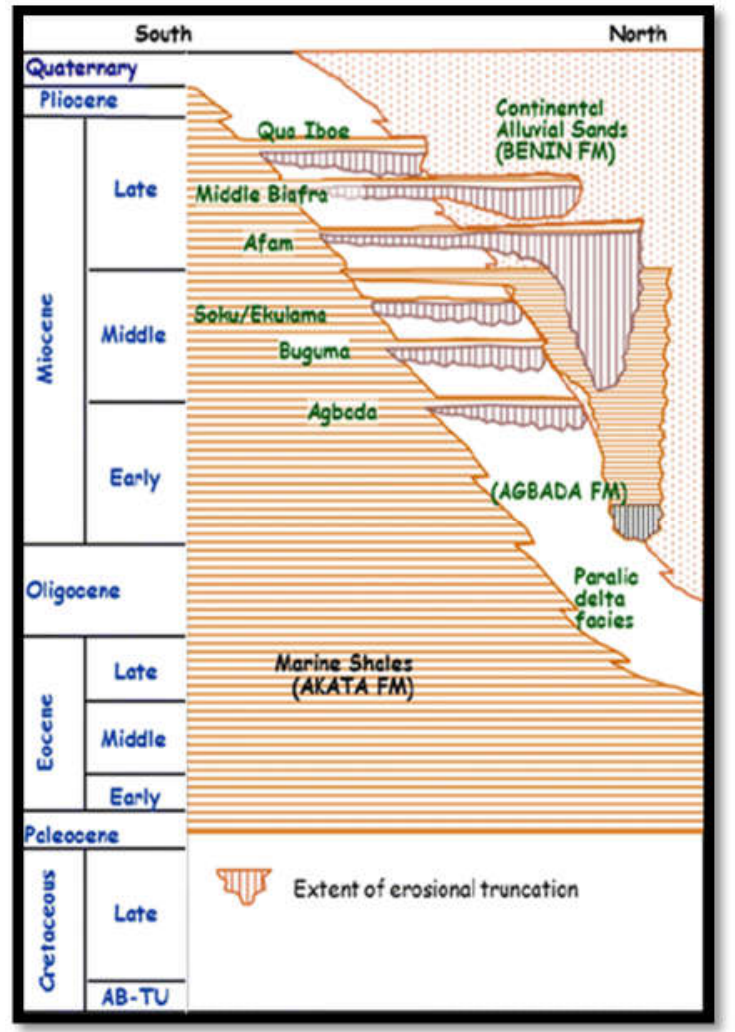

Fig 2: Regional stratigraphy of the Niger Delta showing different Formations (after Ozumba, 2013).

Determination of sandstone and shale Lithology: Given data in ASCII format were used to generate sets of wireline logs (gamma ray, resistivity, neutron and density log) using the Petrel software which were presented at steady processes to enhance log developments and as well to support the trend of facies stacking patterns. The interpretation of well log responses (gamma-ray and resistivity logs) was established with ditch cutting features of sediments evaluated using both visual inspection and reflected binocular microscopy. The Gamma-ray log was utilized to define the lithologies at the depth intervals. The higher the value of the log signature the more shalier is the Formation. Sandstones that is clean usually reveals a low level of natural radioactivity, while clay minerals and fluid particles in shales show higher levels of radioactivity owing to adsorption of the heavy radioactive elements. Sandstones were defined with low API log signatures fluctuating between 0 and 20 API units. Sandy-shales varies from 20 to 100 API units whereas shales have API unit as from 100 and above. This illustrates reduction in the rate of sedimentation and general reduction in energy, recognized as fluvial environments and transgress sequences. The outlining method enabled us to estimate and establish the lithological sequence of the Formations of the study area.
Biostratigraphic analyses: The standard micropaleontological preparation technique for foraminiferal and palynological samples were used in the Laboratory. The palynological analysis involved the use of standard palynological preparation for recovering acid insoluble organic-walled microfossils from sediments with the technique of Wood et al., (1996), which is the use of $\mathrm{HCl}, \mathrm{HF}, \mathrm{HNO}_{3}$ involving heavy-liquid separation with $\mathrm{ZnBr}_{2}(2.2$ s.g.) and separating of the remains with a $20 \mu \mathrm{m}$ sieve. Foraminiferal and palynology slides were examined using reflected and transmitted light binocular microscopes respectively. The distribution chart (statistical data) of the specimens were documented and StrataBugs software was used for data processing and integration with the well logs data. The absolute ages of the foraminiferal and palynomorphs biozones, maximum flooding surfaces and the third order sequence boundaries were based on correlation zones and cycles of numerous authors such as Blow, (1969, 1979); Bolli and Saunders, (1985); Germeraad et al., (1968); Evamy et al., (1978); Legoux, (1978).

Sequence Stratigraphy: Wireline logs, sedimentology and biostratigraphic data (foraminiferal and palynology) were integrated to construct sequence stratigraphic framework based on the approach of Armentrout et al., (1990). Variations in stacking patterns as observed on the produced gamma ray log aided the recognition of systems tracts. The microfaunal and micro floral zonation scheme chart of Haq et al., (1988) was utilized to delineate numerical stage boundaries of MFSs and SBs identified. The concepts of Emery, (1993) were employed to delineate the depositional sequences. The well log patterns were used to define the sequences to diverse categories of systems tracts.

Well correlation: FX-1 well with intervals $15 \mathrm{ft}$. $10,185 \mathrm{ft}$. was selected as the composite standard section (CS) for the study area due to its depth, most closely sampled, having abundant fossil and quite widespread with no indication of main facies breaks. The depths of the Oligocene/Miocene boundary were taken for both wells. Using the petrel software, sedimentological, palynological, foraminiferal and sequence stratigraphy interpreted for both wells formed the basis of correlation.

\section{RESULTS AND DISCUSSION}

Sequence Stratigraphic Interpretation of both wells are provided as follows. The highest value of a retrogradational stacking pattern of the gamma ray $\log$, is inferred as candidate maximum flooding surface while low value of a progradational stacking 
pattern is deduced as sequence boundary and starting of a subsequent transgression.

The recognized sequence boundaries were considered by significant sand unit and low gamma ray value. It is the interval separating the overlying shallow microfacies from underlying deep water facies with minimal biofacies abundance and diversity. Also, recognized as the zone of most basin ward shift in marine biofacies which correspond with coarsening upward sequence.

The MFSs are categorized by dense and widespread mudstone components identified by high gamma-ray value and lowest resistivity readings. (Vail and Wornardt, 1990). They most often indicate sedimentation rates. Armentrout and Clement, (1990), with maximal biofacies abundance and diversity.

From the faunal and floral abundance / diversity peaks, seven candidate sequence boundaries were encountered dated 33.3 Ma, 29.3 Ma, 27.3 Ma, 24.9 $\mathrm{Ma}, 23.7 \mathrm{Ma}, 22.2 \mathrm{Ma}$ and $21.8 \mathrm{Ma}$ and eight candidate maximum flooding surfaces were identified dated 34.0 Ma, 33.0 Ma, 31.3 Ma, 28.1 Ma, 26.2 Ma, 24.3 Ma, 23.2 Ma and 22.0 Ma respectively. The varying depths at which these shales were found are shown in Tables 1 and 2.

Five and four depositional sequences are identified in both FX-1 and FX-2 wells. The Sequences are further divided into para-sequences and their associated systems tracts, namely Highstand systems tract (HST) and Transgressive systems tract (TST). The Systems tracts of the study area are shown in Tables 1 and 2, Figs. 3 and 5. The shaded portions in both tables are the undiagnostic intervals of the wells due to the missing / unidentified sequence boundaries.

Depositional sequences interpretation in FX-1 well: Five depositional sequences (SQ1-SQ5) were demarcated with eight maximum flooding surfaces and seven sequence boundaries. The depositional sequences are discussed below from the oldest interval to the youngest intervals. Table 1, Figs. 3 and 4.

Depositional Sequence 1 (SQ1, 6115 ft. - 6656 ft.): This depositional sequence starts at depth $6656 \mathrm{ft}$. and end at $6115 \mathrm{ft}$. of $541 \mathrm{ft}$. thick. The interval falls between SB 29.3 Ma and SB 27.3 Ma which is of the $3^{\text {rd }}$ order cycle based on the identification of the unit boundaries. The interval of the transgressive systems track (6362 ft. - $6656 \mathrm{ft}$.) shows a retrogrational parasequence pattern consisting dominantly of pelagic shale with some transgressive sand sediments and terminate at maximum abundance and diversity of foraminiferal assemblages called the maximum flooding surface (MFS) at depth $6362 \mathrm{ft}$. dated 28.1 Ma. The overlying HST interval (6115 ft. - $6362 \mathrm{ft}$.) consist of shale unit at the base and progressively into a progradational stacking pattern with sand increasing upwards to terminate at the base of cylindrical log shape marking the sequence boundary at $6115 \mathrm{ft}$. dated 27.3 Ma. The HST is further constrained by decreasing-upward foraminiferal and palynomorphs abundance/diversities and shoaling-upward profile.

Depositional Sequence 2 (SQ2, $5639 f t$. - $6115 f t$.): The top of this depositional sequence is at $5639 \mathrm{ft}$. and the base at $6115 \mathrm{ft}$. with a thickness interval of (476 ft.). The interval falls between SB 27.3 Ma and SB 24.9 Ma which is of the $3^{\text {rd }}$ order cycle based on the identification of the unit boundaries. The interval of the transgressive systems track (5752 ft. - $6115 \mathrm{ft}$.) start with a progradational stacking pattern that finally shows a retrogrational parasequence pattern consisting dominantly of pelagic shale with maximum abundance and diversity of foraminiferal assemblages topped by the maximum flooding surface at $5752 \mathrm{ft}$. dated 26.2 Ma. The overlying HST interval (5639 ft. - $5752 \mathrm{ft}$.) consist of sand and shale intercalations with sand increasing upwards to terminate at base of cylindrical $\log$ shape marking the sequence boundary at $5639 \mathrm{ft}$. dated 24.9 Ma.

Depositional Sequence 3 (SQ3, 5424 ft. - $5639 f t$.): The sequence episode of deposition starts at depth of 5639 $\mathrm{ft}$. and ends at $5452 \mathrm{ft}$. of $215 \mathrm{ft}$. thick. The interval falls between SB 24.9 Ma and SB 23.7 Ma which is of the $3^{\text {rd }}$ order cycle based on the identification of the unit boundaries. The interval of the transgressive systems track $(5507 \mathrm{ft}$. - 5639 ft. $)$ starts with a progradational stacking pattern that finally shows a retrogrational parasequence pattern consisting dominantly of pelagic shale with maximum abundance and diversity of foraminiferal overlaid by the maximum flooding surface at $5507 \mathrm{ft}$. dated 24.3 Ma. The overlying HST interval ( $5424 \mathrm{ft}$. - $5507 \mathrm{ft}$.) consist of sand and shale intercalations with sand increasing upwards to terminate at the base of cylindrical log shape marking the sequence boundary at $5424 \mathrm{ft}$. dated 23.7 Ma.

Depositional Sequence 4 (SQ4, $4859 f t$. - $5424 f t$.): The depositional sequence starts at depth of $5424 \mathrm{ft}$. and ends at $4859 \mathrm{ft}$. of $565 \mathrm{ft}$. thick. The interval falls between SB 23.7 Ma and SB 22.2 Ma which is of the $3^{\text {rd }}$ order cycle based on the identification of the unit boundaries. The interval of the transgressive systems track (5161 ft. - $5424 \mathrm{ft}$.) start with a progradational stacking pattern that finally shows a retrogrational parasequence pattern consisting dominantly of pelagic 
shale capped by the maximum flooding surface at $5161 \mathrm{ft}$. dated 23.2 Ma. The overlying HST interval (4859 ft. - $5161 \mathrm{ft}$.) consist of sand and shale intercalations. The sequence boundary at $4859 \mathrm{ft}$. dated $22.2 \mathrm{Ma}$ is further constrained by minima abundance and diversity of palynomorphs recovered from the interval.

\begin{tabular}{|c|c|c|c|c|c|c|c|c|}
\hline Systems tracts & Depth (ft.) & Key surfaces & Age (Ma) & $\begin{array}{l}\text { Depositional } \\
\text { sequence }\end{array}$ & $\begin{array}{l}\text { Thickness } \\
\text { (it.) }\end{array}$ & $\begin{array}{c}\text { Depth } \\
\text { interval (t.) }\end{array}$ & $\begin{array}{c}\text { Palynological } \\
\text { zone }\end{array}$ & Epoch \\
\hline HST & 4581 - $4816(235)$ & SB 7 @ 4581 ft. & 21.8 & \multirow[b]{2}{*}{5} & \multirow[b]{2}{*}{278} & \multirow[b]{2}{*}{$4859-4581$} & \multirow{2}{*}{ P630 } & \multirow{18}{*}{$\frac{a}{2}$} \\
\hline TST & $4816-4859(43)$ & MFS 8 @ 4816 ft. & 22.0 & & & & & \\
\hline HST & $4859-5161(302)$ & SB6@ 6859 ft. & 22.2 & \multirow[b]{2}{*}{4} & \multirow[b]{2}{*}{565} & \multirow[b]{2}{*}{$5424-4859$} & \multirow{3}{*}{ P620 } & \\
\hline TST & $5161-5424(263)$ & MFS 7@ $5161 \mathrm{ft}$ & 23.2 & & & & & \\
\hline HST & $5424-5507(83)$ & SB $5 @$ Q $5424 \mathrm{ft}$. & 23.7 & \multirow[b]{2}{*}{3} & \multirow[b]{2}{*}{215} & \multirow[b]{2}{*}{$5639-5424$} & & \\
\hline TST & $5507-5639(132)$ & MFS 6@ $5597 \mathrm{ft}$. & 24.3 & & & & \multirow{4}{*}{ P580 } & \\
\hline HST & $5639-5752(113)$ & SB 4 @ $5639 \mathrm{ft}$ & 24.9 & \multirow[b]{2}{*}{2} & \multirow[b]{2}{*}{476} & \multirow[b]{2}{*}{$6115-5639$} & & \\
\hline TST & $5752-6115(363)$ & MFS $5 @ 5752 \mathrm{ft}$ & 26.2 & & & & & \\
\hline HST & $6115-6362(245)$ & SB3@ @6115ft. & 27.3 & \multirow{4}{*}{1} & \multirow{4}{*}{541} & \multirow{4}{*}{$6656-6115$} & & \\
\hline TST & $6362-6656$ (294) & MFS 4@ 6362 ft. & 28.1 & & & & \multirow{3}{*}{ P560 } & \\
\hline & & & & & & & & \\
\hline \multirow[t]{3}{*}{ HST } & $6656-9437$ (2781) & SB 2@ $9656 \mathrm{ft}$. & 29.3 & & & & & \\
\hline & & MFS3@9437 ft & 313 & & & \multirow{6}{*}{$10172-9437$} & \multirow{6}{*}{ ?P540 - P520 } & \\
\hline & & SB 2 Missing & 32.4 & & & & & \\
\hline TST & $9509-9616(107)$ & MFS 2 Q $9500 \mathrm{ft}$ & 33.0 & & & & & \\
\hline & & & & & & & & \\
\hline$\frac{\text { HST }}{\text { TST }}$ & $9616-10011(395)$ & SB1 @ 9616 ft. & 33.3 & & & & & \\
\hline TST & $10011-10,172(161)$ & MFS 1 a $10011 \mathrm{ft}$ & 34.0 & & & & & \\
\hline
\end{tabular}

\begin{tabular}{|c|c|c|c|c|c|c|c|c|}
\hline Systems tracts & Depth (tt.) & Key surfaces & Age (Ma) & $\begin{array}{c}\text { Depositional } \\
\text { sequence }\end{array}$ & Thickness (ft.) & $\begin{array}{c}\text { Depth } \\
\text { interval (ft.) }\end{array}$ & $\begin{array}{c}\text { Palynological } \\
\text { zone }\end{array}$ & Epoch \\
\hline HST & $5542-5571(29)$ & SB 5 @ $5542 \mathrm{ft}$. & 23.7 & \multirow[b]{2}{*}{4} & \multirow[b]{2}{*}{111} & \multirow[b]{2}{*}{$5653 \cdot 5542$} & \multirow{3}{*}{ P620 } & \multirow{12}{*}{ है } \\
\hline TST & 5571 - $5653(82)$ & MFS 5 @ $5571 \mathrm{ft}$. & 24.3 & & & & & \\
\hline & & SB $4 @$ @ 5653 ft. & 24.9 & \multirow[b]{2}{*}{3} & \multirow[b]{2}{*}{35} & \multirow[b]{2}{*}{$5688-5653$} & & \\
\hline & & Missing MFS & 26.2 & & & & \multirow{2}{*}{ P580 } & \\
\hline HST & $5688-5862(174)$ & SB 3 @ $5688 \mathrm{ft}$. & 27.3 & \multirow[b]{2}{*}{2} & \multirow[b]{2}{*}{341} & \multirow[b]{2}{*}{$6029 \cdot 5688$} & & \\
\hline TST & $5862-6029(167)$ & MFS $4 @ 5862 \mathrm{ft}$. & 28.1 & & & & \multirow{2}{*}{ P560 } & \\
\hline HST & $6029-6721(692)$ & SB $2 @ 6029 \mathrm{ft}$. & 29.3 & \multirow{3}{*}{1} & \multirow{3}{*}{912} & \multirow{3}{*}{$6941-6029$} & & \\
\hline TST & $6721-6941(220)$ & MFS 3 @ $6721 \mathrm{ft}$. & 31.3 & & & & \multirow{2}{*}{ P540 } & \\
\hline \multirow[t]{3}{*}{ HST } & $6941-7196(255)$ & SB 1 @ $6941 \mathrm{ft}$. & 324 & & & & & \\
\hline & & MFS 2 @ 7164ft. & 33.0 & & & \multirow{3}{*}{$7764 \cdot 7164$} & \multirow{3}{*}{ P520 } & \\
\hline & & SB 1 Missing & 333 & & & & & \\
\hline TST & $7764-8300(536)$ & MFS1@ 7764ft. & 34.0 & & & & & \\
\hline
\end{tabular}

Depositional Sequence 5 (SQ5, $4581 \mathrm{ft}$. - $4859 \mathrm{ft}$.): This is the youngest depositional sequence and starts at depth $4859 \mathrm{ft}$. and ends at $4581 \mathrm{ft}$. with $278 \mathrm{ft}$. thick. The interval falls between SB 22.2 Ma and SB 21.8 Ma which is of the $4^{\text {th }}$ order cycle based on the identification of the unit boundaries. The interval of the transgressive systems track $(4816 \mathrm{ft}$. $4859 \mathrm{ft}$.) is capped by the maximum flooding surface at $4816 \mathrm{ft}$. dated 22.0 Ma. The overlying HST interval (4581 ft. - $4816 \mathrm{ft}$.) is capped by sequence boundary at $4581 \mathrm{ft}$. dated $21.8 \mathrm{Ma}$. Absence of gamma ray log and foraminiferal data within the shallow interval analyzed. These key surfaces were constrained by maximum / minimal abundance and diversity of palynomorphs recovered from the interval.
Depositional

sequences interpretation in $\mathrm{FX}-2$ well: Four depositional sequences (SQ1-SQ4) with five maximum flooding surfaces and five sequence boundaries were delineated. The depositional sequences are discussed below. Table 2, Figs. 5 and 6. 


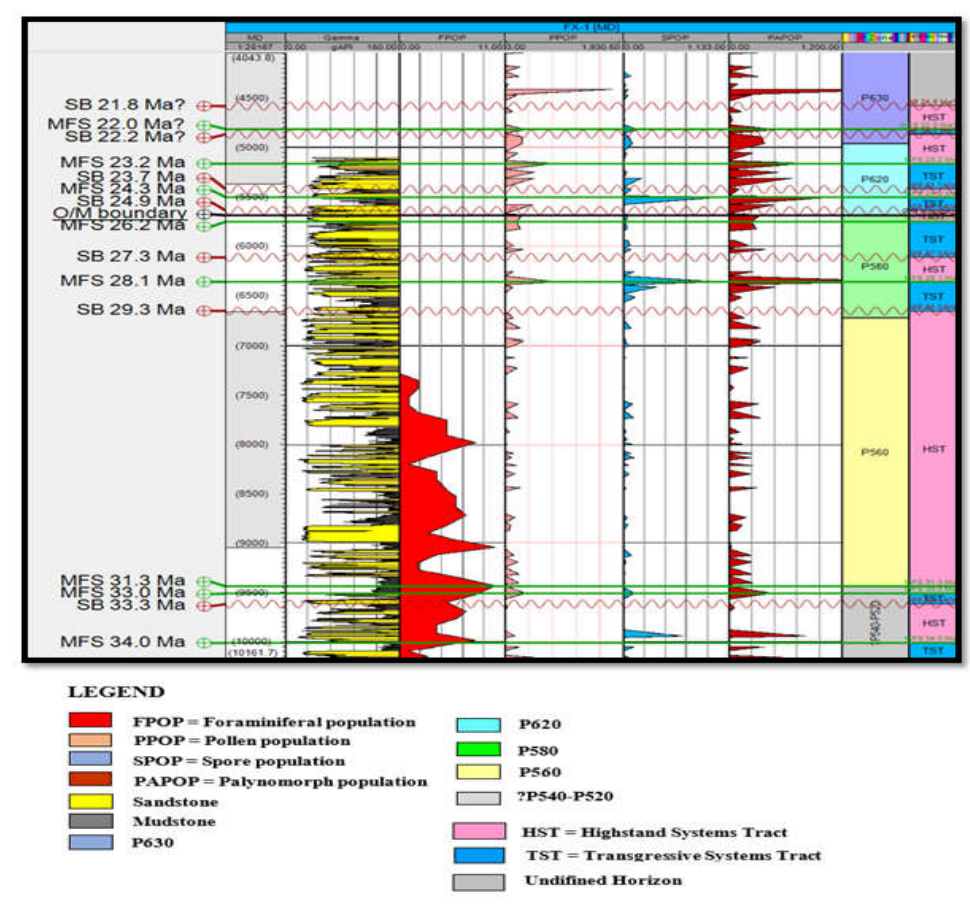

Fig. 3: Sequence stratigraphic framework for FX-1 well

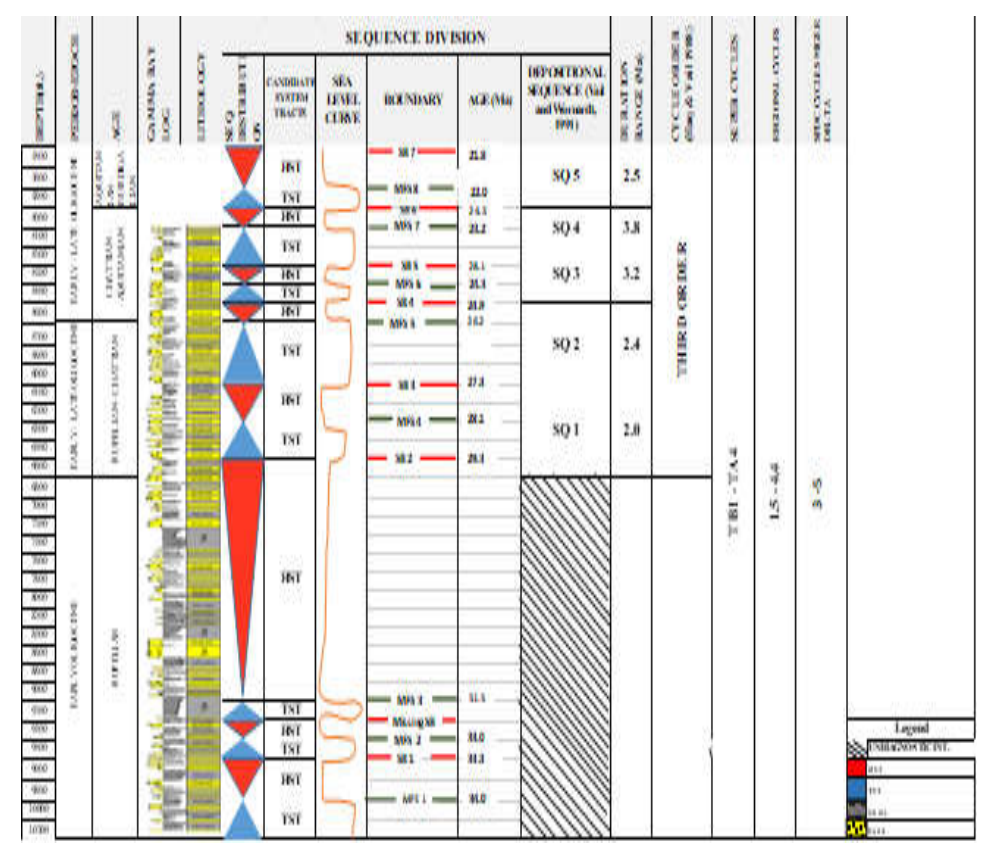

Fig. 4: Sequence Stratigraphic Established for FX-1 Well.

The interval of the transgressive systems track (6721 ft.- $6941 \mathrm{ft}$.) shows a progradational stacking pattern with retrogrational parasequences pattern consisting dominantly of pelagic shale capped on top by maximum flooding surface at $6721 \mathrm{ft}$. dated $31.3 \mathrm{Ma}$. The overlying HST interval (6029 ft.- $6721 \mathrm{ft}$.) consist of sand unit at the base and progressively with intercalations of shale and sand and finally capped on top by sand marking the sequence boundary at $6029 \mathrm{ft}$. dated $29.3 \mathrm{Ma}$. The HST is further constrained by decreasing-upward foraminiferal and palynomorphs abundance/diversities and shoaling-upward profile.
Depositional Sequence 2 (SQ2, $5688 \mathrm{ft}$. - $6029 \mathrm{ft}$.): The sequence episode of deposition commenced at depth $6029 \mathrm{ft}$. and ends at $5688 \mathrm{ft}$. of $341 \mathrm{ft}$. thick which falls within SB 29.3 Ma and SB 27.3 Ma of the $3^{\text {rd }}$ order based on the identification of unit boundaries.

The TST (5862 ft. - 6029 ft.) consists of dominantly shale with some thin transgressive sand sediments and terminate at maximum abundance and diversity of foraminiferal assemblages called the maximum flooding surface at $5862 \mathrm{ft}$. dated 28.1 Ma.

The HST is between the intervals of (5688 ft. - $5862 \mathrm{ft}$.) characterized by thick shale unit with thin intercalations of sand increasing upwards to terminate at base of sand marking the sequence boundary at $6688 \mathrm{ft}$. dated 27.3 Ma.

Depositional Sequence 3 (SQ3, $5653 \mathrm{ft}$. - $5688 \mathrm{ft}$.): The depositional sequence commenced at depth of $5688 \mathrm{ft}$. and ends at $5653 \mathrm{ft}$. of $35 \mathrm{ft}$. thick which falls within SB 27.3 Ma and SB $24.9 \mathrm{Ma}$ of the $3^{\text {rd }}$ order based on the identification of unit boundaries. The TST and HST could not be ascertain because of the missing MFS (26.2 Ma) within the interval.

Depositional Sequence 4 (SQ4, $5542 \mathrm{ft}$. - $5653 \mathrm{ft}$.): This is the youngest sequence which starts at $5653 \mathrm{ft}$. and ends at $5542 \mathrm{ft}$. of 111 ft. thick. This interval falls within SB 24.9 Ma and SB 23.7 Ma of the $3^{\text {rd }}$ order based on the identification of unit boundaries.

The TST (5571 ft. - 5653 ft.) consists of dominantly sand at the base with some thin transgressive shale sediments and progressively into shale which terminate at maximum abundance and diversity of foraminiferal assemblages called the maximum flooding surface at $5571 \mathrm{ft}$. dated 24.3 Ma. 


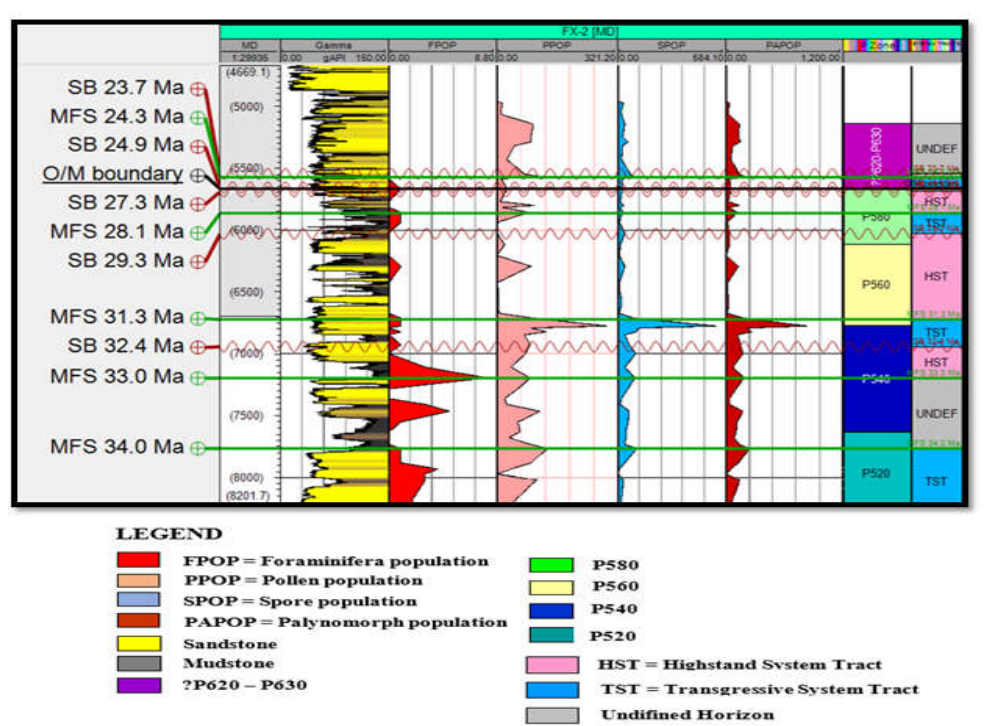

Fig 5: Sequence stratigraphic for FX-2 well.

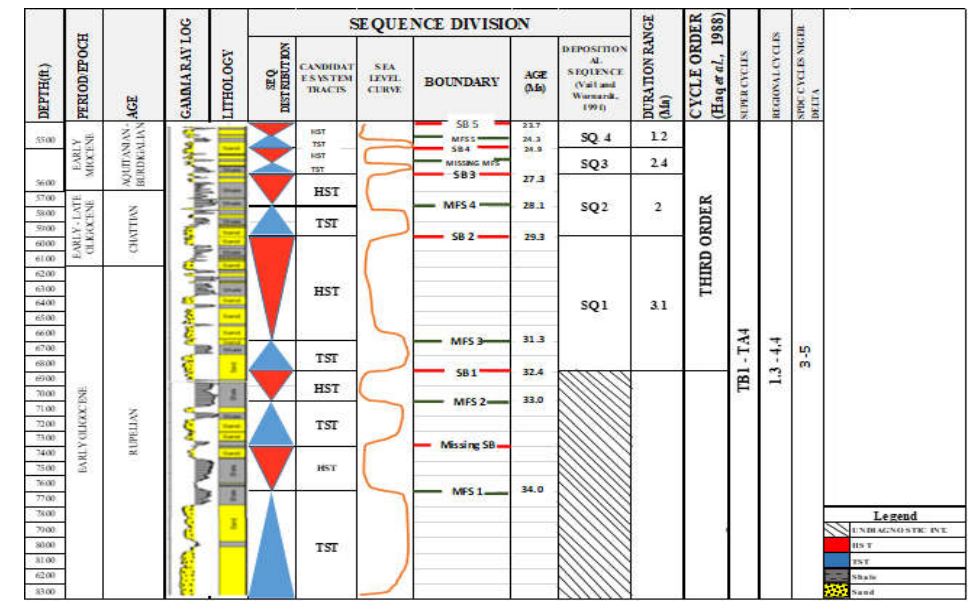

Fig. 6: Sequence Stratigraphic Established for FX-2 Well

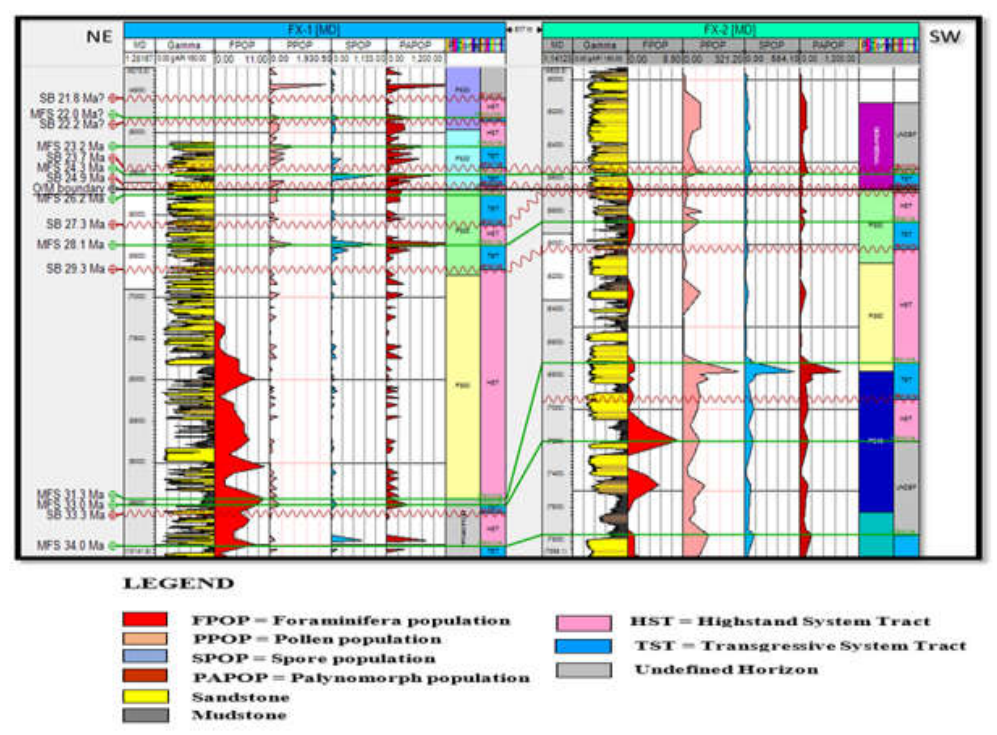

Fig 7: NE-SW cross section chronostratigraphic correlation between the two wells
The HST is between the intervals of (5542 ft. - $5571 \mathrm{ft}$.) characterized by sand unit with thin intercalations of shale increasing upwards to terminate at base of sand marking the sequence boundary at $5542 \mathrm{ft}$. dated 23.7 Ma. Due to the missing SB 32.4 Ma in FX-1 well, SB 33.3 Ma and MFS 26.2 Ma in FX-2 well, intervals between $6656 \mathrm{ft}$. - 10,172 $\mathrm{ft}$. in FX-1 well and from $6941 \mathrm{ft}$. $8300 \mathrm{ft}$. in FX-2 well could not be constrained. This may indicate Oligocene hiatus.

Chronostratigraphic Correlation: Chronostratigraphic correlation is related with the idea of comparing rock sediments in two geographic areas having the same marker fossil specimen which indicates that the sediments were deposited probably at the same time frame. In line with Jaramillo et al., (2009), the correlation analysis for the studied wells started by indicating FX-1 well with intervals $15 \mathrm{ft}$. $-10,185 \mathrm{ft}$. as the composite standard section (CS) due to its depth of penetration, sampled at close depth, abundant fossil with varieties reasonably wide-ranged.

The significant candidate chronostratigraphic datum defined from both wells are MFSs: $34.0 \mathrm{Ma}$, 33.0 Ma, 31.3 Ma, 28.1 Ma, 26.2 Ma, 24.3 Ma, 23.2 Ma and 22.0 Ma as well as $33.3 \mathrm{Ma}, 29.3 \mathrm{Ma}, 27.3$ Ma, 24.9 Ma, 23.7 Ma, 22.2 Ma and 21.8 Ma SBs. The stacking patterns, systems tracts and chronostratigraphic surfaces established in FX-1 to FX-2 wells were compared. Of these time significant surfaces, five candidate MFS's (34.0 Ma, 33.0 Ma, 31.3 Ma, $28.1 \mathrm{Ma}$ and $24.3 \mathrm{Ma}$ ) and four candidate SB's (29.3 Ma, 27.3 Ma, 24.9 $\mathrm{Ma}$ and $23.7 \mathrm{Ma}$ ) correlated across both wells. The Oligocene/Miocene boundary for FX-1 and FX-2 wells (5688 ft. and $5665 \mathrm{ft}$.) also correlated across both wells. 
However, MFS's 26.2 Ma, 23.2 Ma, 22.0 Ma and SB's 33.3 Ma, 22.2 Ma, 21.8 Ma and 20.4 Ma were not correlated across wells probably due to nondeposition, eroded or non-identified stacking pattern and may indicate Oligocene hiatus. Fig. 7. With the aid of sedimentological / wire line data and obtainable biostratigraphic information, regional geologic correlation has been carried out across the area of study from Well-1 through Well 2.

Conclusion: The study identified five and four depositional sequences in both FX-1 and FX-2 wells. Also, eight candidate MFSs dated $34.0 \mathrm{Ma}, 33.0 \mathrm{Ma}$, 31.3 Ma, 28.1 Ma, 26.2 Ma, 24.3 Ma, 23.2 Ma and 22.0 Ma and seven candidate SBs dated 33.3 Ma, 29.3 Ma, 27.3 Ma, 24.9 Ma, 23.7 Ma, 22.2 Ma and 21.8 Ma, respectively. Five candidate MFS's (34.0 Ma, 33.0 Ma, 31.3 Ma, 28.1 Ma and 24.3 Ma) and four candidate SB's (29.3 Ma, 27.3 Ma, 24.9 Ma and 23.7 Ma) correlated across both wells. The correlation of the two wells and sequence stratigraphic interpretation is a supplementary understanding of the subsurface geology of the study area.

Acknowledgment: The authors sincerely acknowledge the Nigerian Petroleum Development Company (NPDC) of Nigeria for the provision of the ditch cutting samples and ASCII data used for this research work. Special thanks are due to $\mathrm{Mr}$. Ebenezer Bamigboye for his cooperation, fruitful discussion and Mrs. Esther Ozeale for her assistance with computer software during the research work.

\section{REFERENCES}

Ajayi, EO; Okosun, EA (2014). Planktic foraminiferal Biostratigraphy of A, B, C, D Wells, Offshore Niger Delta, Nigeria. American International Journal of Contemporary Research 4(6): 108 120.

Alege, TS (2017). Sequence Stratigraphy of Akos Field of the Coastal Swamp Depobelt of the Niger Delta. Advances in Applied Science Research 8(1): $16-27$.

Armentrout, JM; Echols, RJ; Lee, TH (1990). Patterns of foraminiferal Abundance and Diversity: Implications for Sequence Stratigraphic Analysis. In: Sequence Stratigraphic as an Exploration Tool: Concepts and Practices in the Gulf Coast. Gulf Coast Section SEPM Foundation Eleventh Annual Research Conference Program and Abstracts, Vol. 21, pp. 53 - 58.

Armentrout, JM (1995). "High Resolution Sequence Biostratigraphy: Examples from the Gulf of
Mexico, Pliocene-Pleistocene." Geological Society Special Publication. 104: 65 - 86.

Blow, WH (1969). Late Middle Eocene to Recent planktonic foraminiferal biostratigraphy. In Bronnimann, P; Renz, HH (eds.), Proceedings of the First International Conference on Planktonic Microfossils, Geneva, E. J. Brill, Leiden, Vol. 1, pp. $199-422$.

Bolli, HM; Saunders, JB (1985). Oligocene to Holocene low latitude planktic foraminiferal, in HM. Bolli, JB. Saunders and K. Perch-Nielsen, eds., Plankton stratigraphy. New York, Cambridge University Press, 1: 155 - 257.

Doust, B; Omatsola, E (1990). Niger Delta, in, Edwards, JD; Santogrossi, PA., eds., Divergent/passive Margin Basins., AAPG Memoir 48: Tulsa, American Association of Petroleum Geologists. 239 - 248.

Emery, A (1993). Transgressive-regressive (T-R) sequence analysis of the Jurassic succession of the Sverdrup Basin Canadian Arctic Achipelago: Canadian Jour. Of Earth Science, 30: 301 - 320.

Esan, AO (2002). High resolution sequence stratigraphic and reservoir characterization studies of D-07, D-08 and E-01 sands, Block 2 Meren Field, Offshore, Niger Delta,' Publ. M.S. Geology Thesis, Texas A \& M University, Texas, USA, 115.

Evamy, BD; Haremboure, J; Kamerling, P; Knaap, WA; Molloy, FA; Rowlands, PB (1978). Hydrocarbon habitat of Tertiary Niger Delta. American Association of Petroleum Geologists Bulletin. 62: 1 - 39.

Galloway, WE (1989a). "Genetic stratigraphic sequences in basin analysis I: Architecture and genesis of flooding-surface bounded depositional units". American Association of Petroleum Geologists Bulletin 73: 125 - 142.

Germeraad, JH; Hopping, CA; Muller, J (1968). Palynology of Tertiary sediments from tropical areas: Review of Paloebotany and Palynology, 6: 189 - 348 .

Haq, BU; Hardenbol, JS; Vail, PR (1988). Mesozoic and Cenozoic Chronostratigraphy and cycles of sea-level change. In: Wilgus, CK; Hastings, BS; Kendall, CG; Posamentier, HW; Ross, CA; Van Wagoner, JC (Eds.), Sea-level Changes: $A n$ 
Integrated Approach. SEPM Special Publication, 42: 72 - 108 .

Hart, B (2005). Sequence stratigraphy basics and seismic geometries and patterns of reflector terminations, in Mancini, E.A. (ed.), Sequence stratigraphy for explorationists, Petroleum Technology Transfer Council (PTTC), Eastern Gulf Region, Jackson, Mississippi, 541.

Ifeoluwadun, A; Saka, AO (2018). Foraminiferal Biostratigraphy of Opolo-5 Well Western Niger Delta, Nigeria International Journal of Advanced Scientific Research and Management, 3 (1): 39 48.

Jaramillo, CA; Rueda, M; Bayona, G; Santos, C; Florez, P; Parra, F (2009). Biostratigraphy breaking paradigms: dating the mirador formation in the llanos basin of Colombia. In: Demchuk, T. (Ed.), Biostratigraphic Applications, SEPM Special Publication, Vol. 93, pp. 29 - 40.

Obaje, SO (2013). Sequence Stratigraphic Interpretation of Kafe-1 Field, Offshore Western Niger Delta, Nigeria. International Journal of Engineering Science Invention. 2: 20 - 30

Legoux, O (1978). Quelques especes de pollen caracteristiques du Neogene du Nigeria: Bull. Cent. Rech. Explor. - Prod. Elf-Aquitane, 2 (2): $265-317$.

Ojo, AO; Gbadamosi, AO (2013). Sequence PalynoStratigraphical study of DEL-2 well southwest of the Niger - Delta Basin Nigeria. Research Journal in Engineering and Applied Sciences 2(2): 86 94.

Okengwu, KO; Amajor, LC (2015). Sequence Stratigraphic study of Biwa Field in Greater Ughelli Depobelt, Niger Delta, Nigeria. Scientific Journal Impact Factor. 3: 449.
Ozumba, MB; Amajor, LC (1999). Evolutionary relationships in some benthic foraminiferal of the Middle to Late Miocene, Niger Delta. Nigeria Association of Petroleum Explorationist Bulletin, 14 (1): 157 - 167.

Short, KC; Stauble, AJ (1967). Outline of geology of Niger Delta: American Association of Petroleum Geologists Bulletin, 51: 761 - 779.

Tuttle, LWM; Charpentier, RR; Brownfield, EM (1999). The Niger Delta Petroleum System: Niger Delta Province, Nigeria Cameroon and Equatorial Guinea, Africa. US Geological Survey Open-File Report 99 (50), Denver, 70.

Vail, PR; Wornardt, WW (1990). An integrated approach to exploration and development in the 1990's: Well log seismic sequence stratigraphy analyses, Trans. of the 41st Annual Convention of the Gulf Coast Assoc. of Geological Societies, Houston, Texas, $630-650$.

Van Wagoner, JC; Mitchum, RM; Campion KM; Rahmanian, VD (1990). Siliciclastic sequence stratigraphy in well logs, cores and outcrops: AAPG Methods in Exploration Series, 7.

Weber, KJ; Daukoru, E (1975). Petroleum geology of the Niger Delta: Proceedings of the 9th World Petroleum Congress, Tokyo, 2: 202 - 221.

Whiteman, AJ (1982). Nigeria: It's Petroleum Geology, Resources and Potentials, I \& II, Graham and Trotman, London, 1 - 394.

Wood, GD; Gabriel, AM; Lawson, JC (1996). Palynological techniques - processing and microscopy, in J. Jansonius and DC MaGregor, eds., Palynology: Principles and Applications: American Association of Stratigraphy Palynologists Foundations, 1: 2 